\title{
How to integrate stereotactic body radiation therapy and hypofractionation in the management of stage III lung cancer in the age of immunotherapy
}

\section{Cómo integrar la radioterapia estereotáxica fraccionada y el hipofraccionamiento en el manejo del cáncer de pulmón localmente avanzado en la era de la inmunoterapia}

https://doi.org/10.23938/ASSN.0855

\author{
M. Rico, S. Flamarique Andueza, A. Martín Martínez, MA. Rodríguez Mendizabal, \\ L. Rosas Gutiérrez, E. Martínez López
}

\begin{abstract}
The constant advances in the field of lung cancer immunotherapy have recently reached the treatment of locally advanced disease with the approval of durvalumab after concurrent chemoradiation. However, radiation therapy continues to be key for controlling the disease at this stage. Over the years, different strategies have been employed to try to optimize outcomes using radiotherapy, with cardiac and pulmonary toxicity as the main limitation on its success. The interest in the use of hypofractionation and stereotactic body radiation therapy for stage III non-small cell lung cancer has increased as knowledge regarding these kinds of treatments has been enhanced. Hypofractionation is a relatively frequent treatment, although the level of evidence that supports it is limited. For its part, stereotactic body radiation therapy has been particularly studied as a boost after chemoradiation, with encouraging results. In both cases, study of how to integrate these tools with chemotherapy and particularly with immunotherapy is essential, as they may have an immunomodulatory role.
\end{abstract}

Keywords. Lung cancer. Hypofractionation. SBRT. Immunotherapy.

\section{RESUMEN}

Los constantes avances en el campo de la inmunoterapia en cáncer de pulmón se han visto reflejados en la aprobación de durvalumab para el tratamiento de la enfermedad localmente avanzada tras radioterapia y quimioterapia concurrente. Sin embargo, la radioterapia sigue siendo clave para el control de la enfermedad en este estadio. A lo largo de los años se han utilizado varias estrategias para tratar de optimizar su papel, siendo la toxicidad cardíaca y la pulmonar las principales barreras. En este contexto, el interés por el uso del hipofraccionamiento y la radioterapia estereotáxica fraccionada para el cáncer de pulmón no microcítico estadio III ha ido en aumento. El hipofraccionamiento es un tratamiento relativamente extendido aunque el nivel de evidencia que lo acompaña sea limitado. Por su parte, la radioterapia estereotáxica fraccionada se ha estudiado especialmente como una técnica para sobredosificar áreas concretas de la enfermedad tras el tratamiento con radioquimioterapia. En ambos casos, el estudio de cómo integrar estas herramientas radioterápicas con la quimioterapia, y especialmente con la inmunoterapia, es esencial, dado que pueden jugar además un papel inmunomodulador.

Palabras clave. Cáncer de pulmón. Hipofraccionamiento. SBRT. Inmunoterapia.
Servicio de Oncología Radioterápica. Complejo Hospitalario de Navarra. Pamplona

Recepción: 08/10/2019

Aceptación provisional: 07/11/2019

Aceptación definitiva: 23/12/2019

\section{Correspondencia:}

Mikel Rico Osés

Servicio de Oncología Radioterápica

Complejo Hospitalario de Navarra

C/ Irunlarrea, 3

31008 Pamplona

E-mail: mikel.rico.oses@navarra.es 


\section{INTRODUCTION}

The management of stage III non-small-cell lung carcinoma (NSCLC) is based on the simultaneous administration of chemoradiation (CRT) with conventional fractionation (60-70 Gy x 1.8-2 Gy fractions) followed by durvalumab ${ }^{1}$. Despite the advances achieved with the inclusion of immunotherapy, progression-free survival at 18 months is still below $50 \%$ and locoregional relapse occurs in about $30 \%$ at two years ${ }^{2,3}$. Therefore, there is great interest in optimizing locoregional treatment strategies and radiation therapy (RT) is expected to have a crucial role. The development of the Image-Guided Radiation Therapy (IGRT), the Intensity Modulated Radiation Therapy (IMRT), the Volumetric Modulated Arc Therapy (VMAT), and the acquired knowledge of the role of Stereotactic Body Radiation Therapy (SBRT) and the hypofractionation in various areas of oncology, and particularly in stage I NSCLC, are in favor of investigating their role in the locally advanced disease. Furthermore, this type of treatment may have an immunomodulatory role, which makes it particularly interesting in the era of immunotherapy ${ }^{4}$. On the other hand, hypofractionated schemes are potentially convenient for the patients and cost-effective for health care systems. For all this, further insight on the applications of the SBRT and hypofractionation in stage III NSCLC is necessary. In this article, we aim to review the most relevant studies on the subject and future perspectives.

\section{MATERIAL AND METHODS}

The following search strategy was performed of the PubMed database on June 2019: (lung AND (non small cell OR NSCLC) NOT metast*[TI]) AND (stage III OR locally advanced OR locally-advanced) AND (radiation therapy OR radio-therapy) AND (hypofract* OR SBRT) NOT case reports[Publication Type] in the last 5 years. We searched the National Comprehensive Cancer Network (NCCN), the European Society for Medical Oncology (ESMO), or the American Society for Radiation Oncology (ASTRO) updated guidelines. Finally, we search at the Clinicaltrials.gov database for Locally advanced lung cancer AND (SBRT OR hypofractionation), Recruiting and Not yet recruiting studies. From the PubMed database, 28 out of 48 publications were considered of interest for this work after excluding publications for early stage lung cancer and surgery. From Clinicaltrials.gov database, four out of ten studies fit the scope of this publication.

\section{RESULTS}

\section{Current status of stage III non-small-cell lung carcinoma management}

Stage III NSCLC is a heterogeneous condition that includes diseases with primary tumors larger than seven centimeters without lymph node involvement to disorders with small primary tumors but with multistation lymph node involvement. This has prognostic implications, with differences in 2-year overall survival (OS) up to $30 \%$, as well as from the therapeutic point of view ${ }^{5}$. In the NCCN guidelines, updated in 2019, the main therapeutic option for IIIA stage with N0 or N1 is surgery followed by adjuvant treatment. In the other situations, the level of evidence favors RT treatment with standard fractionation and concomitant chemotherapy (CT) followed by durvalumab, based on the outcomes of the Pacific phase III study published in $2018^{1}$. In this study, patients received concurrent chemoradiation and the administration or not of adjuvant durvalumab was randomized. In the experimental arm with durvalumab median survival was not reached and 2-year OS was $66.3 \%$, while in the control arm the median survival and 2-year OS were 28.7 months and $55.6 \%$, respectively ${ }^{2}$. These are the best results ever published for the management of stage III NSCLC.

From the radiotherapeutic point of view, different strategies have been employed to try to improve clinical results. During the 90s, the use of continuous hyperfractionated accelerated radiotherapy (CHART), administering 54 Gy in 12 days, in three 1.5 Gy fractions per day, increased OS at two years in a nine per cent in comparison to the conventional fractionation ${ }^{6}$. Later, the same hyperfractionated scheme was studied but without treatments on the weekends (CHARTWEL). This time, no differences in survival nor in the control of the disease were observed when compared with conventional fractionation ${ }^{7}$. A metanalysis performed in 2012 
showed that hyperfractionation provided a $2.5 \%$ benefit in 5 -year OS but at the expense of significant increase of esophageal toxicity ${ }^{8}$. A different metanalysis did not report the same results and did not observe the benefits of the hyperfractionated treatment ${ }^{9}$. In the RTOG 9410 trial, the use of hyperfractionated RT with CT did not show any benefit when compared with standard concurrent CRT, although the risk of grade 3 esophagitis doubled. Furthermore, hyperfractionated treatment is a tough therapy from a logistic perspective as well as for the patients. For the above-mentioned reasons, its use has not extended and currently the focus is on other ways of modifying the fractionation.

The RTOG 0617 trial explored the benefits of increasing the dose of RT to $74 \mathrm{~Gy}$. This phase III trial was prematurely closed because the survival in the experimental arm was worse than in the control arm, and it was concluded that increasing the dose to 74 Gy provided no benefits. Median survival in the control arm was 28.7 months (the same as in the control arm in the Pacific study) and the 2-year OS was $58 \%$, while they were 20.3 months and $45 \%$, respectively, in the experimental arm. There were several coincidence factors in the experimental arm that may have contributed to these results, such as the increased doses received by the heart, less adherence to RT protocols, worse compliance to the CT schemes, increased toxicity deaths, and extension of the overall treatment time ${ }^{3,10}$. The use of IMRT and the volume of patients treated by the participating centers may have also influenced the results $^{11,12}$. Still, it is important to highlight that the patients in the Pacific and RTOG 0617 studies, had a performance status (PS) of 0 or 1 , due to inclusion criteria, and median age of 64 years. In routine clinical practice, patient's performance status is frequently two or more, median age at diagnosis is 70 years, and they often have comorbidities that complicate treatment administration. In fact, it is estimated that between $55 \%$ and $59 \%$ of the patients are not candidates for concurrent radical CRTs ${ }^{13,14}$

Based on these results, the main clinical guidelines have maintained RT treatment with $60 \mathrm{~Gy}$ to $70 \mathrm{~Gy}$ fractionations at $2 \mathrm{~Gy}$ per fraction as the standard (e.g., NCCN, ESMO or ASTRO $^{1,15,16}$. Nonetheless, the possibility of improving the outcomes by modifying the RT scheme remains under study. Ramroth et al published a meta-analysis examining studies in which subjects were randomized to different RT schemes, including regimes with splits (interruptions of several days), hypofractionation (lower number of fractions with higher doses per fraction), hyperfractionation or dose escalation with conventional fractionation. The results showed that the increase of the bioequivalent dose (BED) of radiation administered without CT improved survival. However, the increase of the RT dose with CT led to worse survival. These results were partially due to the increase in toxicity and was conditioned by the RTOG 0617 study included in the meta-analysis. Nevertheless, the authors concluded that further studies increasing RT doses and using the latest techniques to reduce toxicity should be of interest ${ }^{17}$. On which is the best way to fractionate the doses, some authors hold that hypofractionated schemes, maintaining the overall treatment period below six weeks are potentially more advantageous than hyperfractionation schemes or dose escalation with conventional fractionations ${ }^{18}$.

\section{Hypofractionation}

In 2015, Kaster et al published the most relevant systematic review on hypofractionation in locally advanced NSCLC. It included 33 concomitant or sequential CT and RT studies with over 1,900 patients. What stands out in this review is the great heterogeneity of the fractionations used in the studies, with doses that ranged between 45 Gy to 85.5 Gy with 2.25 Gy to 3.42 Gy per fraction. This significant variety made it difficult to draw conclusions in terms of survival. However, a moderate linear relationship was observed between BED and OS, so a $0.36 \%-0.7 \%$ benefit in terms of OS would be obtained for each $1 \mathrm{~Gy}$ increasing of the BED. The most outstanding adverse effect was acute esophageal toxicity in concurrent treatments, reaching $14.9 \%$. However, the administered BED was not as relevant for the toxicity as it were the doses received by healthy organs, particularly by the proximal bronchial tree $\mathrm{e}^{19,20}$.

A survey carried out in the UK on the most common practices in the treatment of NSCLC -with the participation of 50 centers- it was observed that the most used fractionation was $55 \mathrm{~Gy}$ x 20 fractions of $2.75 \mathrm{~Gy}^{21}$. In fact, in the diagnostic and treatment NICE guidelines for NSCLC updated in 2019, this scheme is presented as an additional alternative for radical treatments $^{22}$. However, there is no strong evidence to support this type of fractionation. The 
most numerous study included 609 patients, from which $72 \%$ did not receive CT and the rest was treated with sequential CT. Eighty-three per cent of the treated patients had stage III NSCLC, and in this group of patients, the median survival was 20 months with $40 \%$ OS at twoyear. No grade 3 or 4 toxicities were detected, implying good tolerance ${ }^{23}$. In 2014 , the results of the SOCCAR study were published in which the same RT scheme of 55 Gy in four weeks was used, comparing the sequential CT treatment against the concurrent CT. Initially, it was planned to be a phase III study, but due to poor recruitment, it was restructured to a phase II study and the main objective of the study was to assess the tolerability of the treatment. The results showed low toxicity, with $9.3 \%$ and $8.2 \%$ grade 3 esophageal toxicity in the concurrent and sequential arms, respectively. Median OS and 2-year OS in the concurrent CRT arm were 25 months and 50\%. According to the authors these are good results that invite making a comparison of this treatment regime against the conventional scheme ${ }^{24}$.

In 2007, Belderbos et $\mathrm{al}^{25}$ published the results of the EORTC group study $08972-22973$ in which patients were randomized to RT with concurrent CT versus sequential CT. The RT scheme was 66 Gy x 24 fractions of 2.75 Gy. Regarding CT, it is worth pointing out that in the sequential arm a scheme of two cycles of cisplatin and gemcitabine was used, while in the concurrent arm cisplatin was administered at low doses $\left(6 \mathrm{mg} / \mathrm{m}^{2}\right)$ on a daily basis. The median of survival and 2-year OS for the concurrent arm was 16.5 months and $39 \%$, respectively; no differences were detected in the sequential arm. However, toxicity was significantly higher in the concurrent arm with acute G3 esophagitis and G3 pneumonitis in 14\% and 18\% of the cases, respectively. That study was prematurely discontinued due to poor recruitment, for which reason it was not possible to draw firm conclusions ${ }^{25}$. Despite that, this RT scheme is still used in common clinical practice in some centers and in new studies. In a phase II Dutch study, the same RT scheme was used (66 Gy x 24 fractions) with concurrent cisplatin at low doses; the addition or not of cetuximab was randomized. Although cetuximab did not provide significant benefits, the results were excellent in both arms in terms of survival (median of 31.5 months and 2-year OS of 59.4\%), comparable to the control arms of the RTOG 0617 and Pacific trials. In this study, the subjects were mostly treated with IMRT and in centers with high volume of patients, unlike to what was done in the RTOG 0617 trial. These aspects have been analyzed as contributing factors for dose escalation not providing any benefit in the RTOG 0617 study $^{26}$. In 2017, a retrospective analysis on cardiac toxicity was published using the same scheme: 66 Gy x 24 fractions and low doses of cisplatin. To date, this is the published study with the higher number of patients $(\mathrm{N}=469)$ treated with this scheme. A relationship between cardiac doses and mortality was observed ${ }^{27}$. In 2017 , Rodríguez de Dios et al treated a group of patients, not candidates for RTCT, with this RT hypofractionated scheme and sequential CT. The results were good, with a median survival of 23 months with no G3 (or higher) toxicities ${ }^{28}$.

There are some interesting differences between the two above-mentioned hypofractionated RT schemes. Applying an alpha/beta of 10, with the limitations the linear-quadratic model may entail, the 55 Gy scheme x 20 fractions would equate to a BED of $70.13 \mathrm{~Gy}$, while the 66 Gy x 24 fractions of 2.75 Gy would equate to $84.15 \mathrm{~Gy}$. The BED corresponding to $60 \mathrm{~Gy}$ $\mathrm{x} 30$ fractions of $2 \mathrm{~Gy}$ is 72 Gy closer to the first scheme than to the second one. Thus, this second scheme may be considered as a dose escalation scheme.

Some publications suggest more aggressive fractionations. During the 2016 ASTRO congress, the preliminary results of a phase III study were presented. In the study, patients with a performance status $\geq 2$, not candidates for concurrent CRT, were randomly assigned to either a treatment of $60 \mathrm{~Gy}$ x 30 fractions versus $60 \mathrm{~Gy}$ x 15 fractions. With a median OS of 11.5 months and with no inter-group differences, the authors concluded that the hypofractionated scheme may be an alternative for these group of patients ${ }^{29}$. During the 2018 ASTRO congress, a phase I study of dose escalation with protons was presented in which most of the patients were treated with 60 Gy x 15 fractions. Local control at two years was $93 \%$ and no severe adverse effects were detected at six months.

The isotoxic radiotherapy is an hypofractionated treatment in which dose escalation on the tumor is performed until the threshold dose for healthy organs is reached. In a phase II study with this RT, carried out by Kong et al, positron emission tomography (PET) was performed in a certain moment of the treatment, and a boost was administered on the observed residual disease. The threshold dose was defined as the dose over which the risk of grade 2 (or greater) pneumonitis was above 17.2\%. In this study, the median dose administered over the tumor was $83 \mathrm{~Gy}$ x 30 fractions and most patients received CT concurrently. Local control at two years was $82 \%$ and OS 25 months $^{30}$. 
The most relevant isotoxic radiotherapy study is RTOG 1106, a phase II study that compares two CRT arms x 30 fractions. In the control arm, patients received $60 \mathrm{~Gy}$ in 30 fractions. In the experimental arm, the first 21 fractions were administered at 2.2 Gy. At fraction 18-19 a PET was performed, and the last nine fractions were applied on the residual disease at doses between 2.2 and 3.8 Gy without exceeding the mean lung dose (20 Gy). With this scheme, it is possible to reach doses of up to $80.4 \mathrm{~Gy}$. It is a hypofractionated, adaptive and isotoxic scheme. Patient recruitment has been completed and results are pending ${ }^{31}$.

\section{Stereotactic Body Radiation Therapy}

The experience acquired in stage I NSCLC -with excellent results- has aroused the interest of using this treatment in other stages of this illness ${ }^{32}$. In fact, SBRT for NSCLC is a very dynamic field and a call upon the thoracic oncology community is being made encouraging the design and development of new studies ${ }^{33}$.

The most studied SBRT potential usefulness is as a boost following conventional CRT. There are at least five publication on the topic, although with a limited number of patients and poor follow-up ${ }^{34,35,36,37,38}$. The most important studies have been carried out at the University of Kentucky. The group published a tolerability study in which the patients underwent CRT consisting of $60 \mathrm{~Gy}$ in 30 fractions and SBRT on the residual lesion smaller than $5 \mathrm{~cm}$ observed in PET. The SBRT dose was 20 Gy in 2 fractions or 19.5 Gy in 3 fractions for medial lesions, surpassing in any case the $100 \mathrm{~Gy} \mathrm{BED} \mathrm{(alfa/beta=10).} \mathrm{Thirty-seven} \mathrm{patients} \mathrm{were}$ treated with a follow-up of 25.5 months. Median survival was 25.2 months with $78 \%$ local control. Grade 3 pneumonitis occurred in $13.5 \%$ of the cases. The authors concluded that it is a safe treatment that does not entail much toxicity compared to what it is expected with conventional CRT ${ }^{35,36}$.

Other groups have developed phase I dose escalation studies with boost following CRT. Higgins et al analyzed four dose levels for overprint: 9 Gy x 2 fractions, 10 Gy x 2 fractions, 6 Gy x 5 fractions and 7 Gy x 5 fractions (accumulated BED: 87 Gy to 112.3 Gy), following 44 Gy of concurrent CRT. Two patients developed grade 5 toxicities (a tracheoesophageal fistula and one case of hemoptysis). Although according to the design of the study, the calculated maximum tolerated dose was 6 Gy x 5 fractions, the authors concluded that 10 Gy x 2 fractions may be a reasonable dose as no grade 5 toxicities were observed with this scheme ${ }^{38}$. On the other hand, Hepel et al also carried out a phase I dose escalation study after CRT with $50.4 \mathrm{~Gy}$, exploring four dose levels for overprint: $8 \mathrm{~Gy} \mathrm{x} 2$ fractions, $10 \mathrm{~Gy}$ x 2 fractions, $12 \mathrm{~Gy}$ $\mathrm{x} 2$ fractions, $14 \mathrm{~Gy}$ x 2 fractions. Locoregional control one year after the treatment was $100 \%$ with boost doses $\geq 24 \mathrm{~Gy}$. One patient died of bronchopulmonary hemorrhage associated to the dose applied to the proximal bronchovascular tree. Based on their results, the authors recommend to limit the doses applied to the bronchovascular tree or increase the number of fractions ${ }^{37}$. The principal studies are summarized in table 1.

Table 1. Clinical outcomes of Stereotactic Body Radiotherapy as boost after radiochemotherapy

\begin{tabular}{|c|c|c|c|c|c|c|}
\hline Study & $\mathbf{N}$ & $\begin{array}{l}\text { RT dose } \\
\text { in RTQT }\end{array}$ & $\begin{array}{c}\text { SBRT } \\
\text { fractionation }\end{array}$ & Local Control & $\begin{array}{c}\text { Overall } \\
\text { Survival }\end{array}$ & Toxicity \\
\hline $\begin{array}{l}\text { Kumar } \\
\text { et } \mathbf{a l}^{36}\end{array}$ & 37 & 60 Gy & $\begin{array}{l}10 \text { Gy x } 2 f x \\
6.5 \text { Gy } x 3 \mathrm{fx}\end{array}$ & $78 \%$ & $\begin{array}{l}25.2 \mathrm{~m} \\
\text { (median) }\end{array}$ & $13.5 \%$ grade 3 pneumonitis \\
\hline $\begin{array}{l}\text { Heppel } \\
\text { et } \mathbf{a l}^{37}\end{array}$ & 12 & $50.4 \mathrm{~Gy}$ & $\begin{array}{c}8 \mathrm{~Gy} \times 2 \mathrm{fx} \\
10 \mathrm{~Gy} \times 2 \mathrm{fx} \\
12 \mathrm{~Gy} \times 2 \mathrm{fx} \\
14 \mathrm{~Gy} \times 2 \mathrm{fx}\end{array}$ & $\begin{array}{c}78 \% \\
100 \% \text { if dose } \geq 24 \mathrm{~Gy}\end{array}$ & 1-y: $67 \%$ & $8 \%$ grade 5 \\
\hline $\begin{array}{l}\text { Higgins } \\
\text { et } \mathbf{a l}^{38}\end{array}$ & 19 & $44 \mathrm{~Gy}$ & $\begin{array}{c}9 \text { Gy x } 2 \mathrm{fx} \\
10 \mathrm{~Gy} \times 2 \mathrm{fx} \\
6 \mathrm{~Gy} \times 5 \mathrm{fx} \\
7 \mathrm{~Gy} \times 5 \mathrm{fx}\end{array}$ & 3-y LRC: $56 \%$ & 3-y: 39\% & $\begin{array}{l}10.5 \% \text { grade } 5 \\
0 \% \text { grade } \geq 3 \text { if } 10 \mathrm{~Gy} \times 2 \mathrm{fx}\end{array}$ \\
\hline $\begin{array}{l}\text { Karam } \\
\text { et }^{3 l^{35}}\end{array}$ & 16 & $50.4 \mathrm{~Gy}$ & 5 Gy x 5 fx & 1-y LC: $42 \%$ & na & $\begin{array}{l}25 \% \text { pneumonitis } \\
0 \% \text { grade } 5\end{array}$ \\
\hline
\end{tabular}

$\mathrm{N}$ : number of patients; RT: radiotherapy; RTQT radiochemotherapy; SBRT: stereotactic body radiotherapy; Gy: gray; fx: fractions; LRC: locoregional control; LC: local control; OS: overall survival; m: months; y: year; na: not available. 
In the study performed by a Korean group in 2018, Kim et al combined CRT for nodal areas and SBRT on the primary lesion, when the targets were distant from each other. With 21 treated patients, 2-year OS was $60.5 \%$, there were no relapses regarding the primary tumor and $14 \%$ of the cases developed grade 3 pneumonitis, all in patients aged over 79 years. The methodological limitations of the study do not allow drawing conclusions but it opens the door to another possible therapeutic application for SBRT ${ }^{39}$.

The use of SBRT has also been examined as part of a multimodal treatment with chemotherapy and surgery in the locally advanced disease. The currently ongoing Linnearre I, is a phase I viability study in which SBRT is given as a neoadjuvant treatment in N0-N1 patients. The goal is to assess the usefulness of SBRT to achieve a larger number of complete resections ${ }^{40}$. In other prospective study published in 2018 by Singh et al, SBRT was employed as an adjuvant treatment after surgery and before adjuvant chemotherapy. A 10 Gy single fraction was applied on the affected stations or in cases of positive margins with good results in terms of local control ${ }^{41}$.

\section{Immunotherapy}

It is known that RT has immune-stimulating effects: it can activate inflammatory pathways, enhance the extravasation of T-cells, promote the maturation of dendritic cells, improve adoptive T-cell transfer and facilitate the recognition of tumoral cells by the immune system $^{42}$. These effects may be more marked with the use of high radiation doses, as in the case of hypofractionated treatments and SBRT ${ }^{4}$. Thus, combining these treatments with immunotherapy, particularly with checkpoint inhibitors, is an interesting field of study due to its potential synergistic effect ${ }^{43}$.

Data from phase I studies indicate that the combination of RT with pembrolizumab in comparison to immunotherapy alone, improves clinical results ${ }^{44}$. Similarly, it has been observed that the combination of antiCTLA-4 therapies and SBRT may favor the response outside the RT field, also promoting clinical benefit ${ }^{45}$. The phase III Pacific trial represents a milestone for the study of the combination of RT and immunotherapy. It has also contributed to the incorporation of durvalumab (an antiPD-L1 antibody) to the standard treatment of phase III NSCLC, with results as never seen before. Furthermore, in diverse experiences in which RT has been combined with immunotherapy, the treatment was well tolerated ${ }^{2}$.

Despite all this, there are still many questions on which are the most appropriate immunotherapeutic agents, the best biomarkers, the ideal sequence for the treatments, the best dose fractionation and how to select the patients. Currently, several ongoing studies will try to provide answers to some of these questions in the following years. Regarding the combination of RT and immunotherapy, the recruitment for the PACIFIC-4 study began in 2019. It is a phase III study comparing SBRT alone versus SBRT followed by durvalumab in patients in early stage NSCLC ${ }^{45}$. Another study that has also begun recruiting recently is the phase II Durvalumab and Consolidation SBRT Following Chemoradiation for Locally Advanced Stage III Non-Small Cell Lung Cancer. In this study patients will undergo concurrent CRT followed by durvalumab, and they will receive SBRT (20 Gy in two fractions or three fractions in medial lesions) on the primary tumor between the first and the second immunotherapy doses ${ }^{46}$. Recruitment of a phase II study that will assess the treatment with RT and concurrent durvalumab followed by durvalumab in stage III NSCLC patients is expected to begin in 2019 too ${ }^{47}$.

\section{CONCLUSIONS}

In the future, hypofractionated RT and SBRT treatments will have a relevant role in the management of stage III NSCLC patients. Hypofractionation may be an appropriate treatment for patients that are not candidates for concurrent CRT therapies. However, randomized prospective studies are necessary to determine how to integrate hypofractionated treatment with concurrent CT and immunotherapy and which is the best fractionation scheme.

The main role of SBRT in the locally advanced disease may be the boost after concurrent CRT treatment although up until now it is only applied in the context of clinical trials. Currently there are ongoing studies that will help define how to integrate SBRT with other type of treatments, particularly with immunotherapy. 


\section{REFERENCES}

1. National Comprehensive Cancer Network. NCCN Guidelines ${ }^{\circledR} \&$ Clinical Resources. Non-Small Cell Lung Cancer 2019; https://www.nccn.org/professionals/physician_gls/pdf/nscl.pdf

2. Antonia SJ, Chiappori A, Gray JE, Villegas A, Merhail T, Daniel D et al. Overall survival with durvalumab after chemoradiotherapy in stage III NSCLC. N Engl J Med 2018; 379: 2342-2350. http://doi.org/10.1056/ NEJMoa1809697.

3. Radiation therapy oncology group RTOG 0617/NCCTG N0628/CALGB 30609/ECOG R0617. A randomized phase III comparison of standard-dose (60 Gy) versus high-dose (74 Gy) conformal radiotherapy with concurrent and consolidation carboplatin/paclitaxel +/- cetuximab (ind \#103444) in patients with stage IIIA/IIIB non-small cell lung cancer. https://www.rtog.org/LinkClick.aspx?fileticket $=$ QU8LgXgAimk\%3D\&tabid $=290$

4. Popp I, Grosu AL, Niedermann G, Duda DG. Immune modulation by hypofractionated stereotactic radiation therapy: therapeutic implications. Radiother Oncol 2016; 120: 185-194. http://dx.doi. org/10.1016/j.radonc.2016.07.013

5. Goldstraw P, Chansky K, Crowley J, Rami-Porta R, Asamura H, Eberhardt Wee et al. The iaSlC lung cancer staging project: proposals for revision of the TNM stage groupings in the forthcoming (eighth) edition of the TNM classification for lung cancer. J Thorac Oncol 2016; 11: 39-51. https://doi.org/10.1097/ JTO.0000000000000334

6. Saunders Mi, Dische S, Barrett A, Parmar MKB, Harvey A, Gibson D. Randomised multicentre trials of CHART vs conventional radiotherapy in head and neck and non-small-cell lung cancer: An interim report. Br J Cancer 1996; 73: 1455-1462. https://doi.org/10.1038/bjc.1996.276

7. Baumann M, Herrmann T, Koch R, Matthiessen W, Appold S, Wahlers B et al. Final results of the randomized phase III CHARTWEL-trial (ARO 97-1) comparing hyperfractionated-accelerated versus conventionally fractionated radiotherapy in non-small cell lung cancer (NSCLC). Radiother Oncol 2011; 100: 76-85. https://doi.org/10.1016/j.radonc.2011.06.031

8. Mauguen A, Le Péchoux C, Saunders MI, Schild SE, Turrisi AT, Baumann M et al. Hyperfractionated or accelerated radiotherapy in lung cancer: an individual patient data meta-analysis. J Clin Oncol 2012; 30 : 2788-2797. https://doi.org/10.1200/jco.2012.41.6677

9. Zhang W, Liu Q, Dong X, Lei P. A meta-analysis comparing hyperfractionated vs. conventional fractionated radiotherapy in non-small cell lung cancer. J Thorac Dis 2015; 7: 478-485. https://doi. org/10.3978/j.issn.2072-1439.2015.02.20

10. Wang K, Eblan MJ, DeAl AM, Lipner M, Zagar TM, WANG Y et al. Cardiac toxicity after radiotherapy for stage III non-small-cell lung cancer: pooled analysis of dose-escalation trials delivering 70 to $90 \mathrm{~Gy}$. J Clin Oncol 2017; 35: 1387-1394. https://doi.org/10.1200/jco.2016.70.0229

11. Eaton BR, Pugh SL, Bradley JD, Masters G, Kavadi VS, Narayan S et al. Institutional Enrollment and Survival among NSCLC Patients Receiving Chemoradiation: NRG Oncology Radiation Therapy Oncology Group (RTOG) 0617. J Natl Cancer Inst 2016; 108: 1-8. https://doi.org/10.1093/jnci/djw034

12. Chun SG, Hu C, Choy H, Komaki RU, Timmerman RD, Schild SE et al. Impact of intensity-modulated radiation therapy technique for locally advanced non-small-cell lung cancer: a secondary analysis of the NRG oncology RTOG 0617 randomized clinical trial. J Clin Oncol 2017; 35: 56-62. https://doi. org/10.1200/jco.2016.69.1378

13. De Ruysscher DKM, Botterweck A, Dirx M, Pijls-Johannesma M, Wanders R, Hochstenbag M et al. Eligibility for concurrent chemotherapy and radiotherapy of locally advanced lung cancer patients: a prospective, population-based study. Ann Oncol 2009; 20: 98-102. https://doi.org/10.1093/annonc/mdn559

14. Al-Shamsi HO, Al FarSI A, Ellis PM. Stage III non-small-cell lung cancer: establishing a benchmark for the proportion of patients suitable for radical treatment. Clin Lung Cancer 2014; 15: 274-280. https:// doi.org/10.1016/j.cllc.2014.02.003

15. Postmus PE, Kerr KM, OudKerk M, Senan S, Waller DA, Vansteenkiste J et al. Early and locally advanced non-small-cell lung cancer (NSCLC): ESMO Clinical Practice Guidelines for diagnosis, treatment and follow-up. Ann Oncol 2017; 28 (Suppl 4): iv1-iv21. https://doi.org/10.1093/annonc/mdx222

16. Rodrigues G, Choy H, Bradley J, Rosenzweig KE, Bogart J, Curran WJ et al. Adjuvant radiation therapy in locally advanced non-small cell lung cancer: executive summary of an American Society for Radiation Oncology (ASTRO) evidence-based clinical practice guideline. Pract Radiat Oncol 2015; 5: 149-155. https://doi.org/10.1016/j.prro.2015.02.013

17. Ramroth J, Cutter DJ, Darby SC, Higgins GS, Mcgale P, Partridge M et al. Dose and fractionation in radiation therapy of curative intent for non-small cell lung cancer: meta-analysis of randomized trials. Radiat Oncol Biol 2016; 96: 736-747. https://doi.org/10.1016/j.ijrobp.2016.07.022

18. Partridge M, Ramos M, Sardaro A, Brada M. Dose escalation for non-small cell lung cancer: analysis and modelling of published literature. Radiother Oncol 2011; 99: 6-11. https://doi.org/10.1016/j.radonc.2011.02.014

19. KASTER TS, YAREMKo B, PALMA DA, RodRigues GB. Radical-intent hypofractionated radiotherapy for locally advanced non-small-cell lung cancer: a systematic review of the literature. Clin Lung Cancer 2015; 16: 71-79. https://doi.org/10.1016/j.cllc.2014.08.002 
20. Cannon DM, Mehta MP, Adkison JB, Khuntia D, Traynor AM, Tomé WA et al. Dose-limiting toxicity after hypofractionated dose-escalated radiotherapy in non-small-cell lung cancer. J Clin Oncol 2013; 1; 31: 4343-4348. https://doi.org/10.1200/jco.2013.51.5353

21. Prewett SL, Aslam S, Williams MV, Gilligan D. The management of lung cancer: a UK survey of oncologists. Clin Oncol 2012; 24: 402-409. https://doi.org/10.1016/j.clon.2012.03.005

22. Collins LG, Haines C. Lung cancer: diagnosis and management. NICE Guidelines (NG122); March 2019. https://www.nice.org.uk/guidance/ng122

23. Din OS, Harden S V., Hudson E, Mohammed N, Pemberton LS, Lester JF et al. Accelerated hypo-fractionated radiotherapy for non small cell lung cancer: results from 4 UK centres. Radiother Oncol 2013; 109: 8-12. https://doi.org/10.1016/j.radonc.2013.07.014

24. McMenemin R, Peedell C, McNee S, Kelly V, Maguire J, O’Rourke N et al. SOCCAR: a randomised phase II trial comparing sequential versus concurrent chemotherapy and radical hypofractionated radiotherapy in patients with inoperable stage III Non-Small Cell Lung Cancer and good performance status. Eur J Cancer 2014; 50: 2939-2949. https://doi.org/10.1016/j.ejca.2014.07.009

25. Belderbos J, Uitterhoeve L, van Zandwijk N, Belderbos H, Rodrigus P, van de VaArt P et al. Randomised trial of sequential versus concurrent chemo-radiotherapy in patients with inoperable non-small cell lung cancer (EORTC 08972-22973). Eur J Cancer 2007; 43: 114-121. https://doi.org/10.1016/j. ejca.2006.09.005

26. Walraven I, Van Den Heuvel M, Van Diessen J, Schake E, Uyterlinde W, Aerts J et al. Long-term follow-up of patients with locally advanced non-small cell lung cancer receiving concurrent hypofractionated chemoradiotherapy with or without cetuximab. Radiother Oncol 2016; 118: 442-446. https://doi. org/10.1016/j.radonc.2016.02.011

27. Stam B, van der Bijl E, van Diessen J, Rossi MMG, Tijhuis A, Belderbos JSA et al. Heart dose associated with overall survival in locally advanced NSCLC patients treated with hypofractionated chemoradiotherapy. Radiother Oncol 2017; 125: 62-65. https://doi.org/10.1016/j.radonc.2017.09.004

28. de Dios NR, Sanz X, Foro P, Membrive I, Reig A, Ortiz A et al. Accelerated hypofractionated radiation therapy (AHRT) for non-small-cell lung cancer: can we leave standard fractionation? Clin Transl Oncol 2017; 19: 440-447. https://doi.org/10.1007/s12094-016-1544-7

29. Choy H, Timmerman RD, Saunders MW, Court LE, Patel MK, Li Y et al. A Phase III randomized study of image guided conventional $(60 \mathrm{~Gy} / 30 \mathrm{fx})$ versus accelerated, hypofractionated (60 Gy/15 fx) radiation for poor performance status stage II and III NSCLC Patients-An Interim Analysis. Int J Radiat Oncol 2016; 96: E451. https://doi.org/10.1016/j.ijrobp.2016.06.1763

30. RoAch MC, Bradley JD, Robinson CG. Optimizing radiation dose and fractionation for the definitive treatment of locally advanced non-small cell lung cancer. J Thorac Dis 2018; 10 (Suppl 21): S2465-S2473 https://doi.org/10.21037/jtd.2018.01.153

31. Ma L, Men Y, Feng L, Kang J, Sun X, Yuan M et al. A current review of dose-escalated radiotherapy in locally advanced non-small cell lung cancer. Radiol Oncol 2019; 53: 6-14. https://doi.org/10.2478/ raon-2019-0006

32. Ball D, Mai GT, Vinod S, Babington S, Ruben J, Kron T et al. Stereotactic ablative radiotherapy versus standard radiotherapy in stage 1 non-small-cell lung cancer (TROG 09.02 CHISEL): a phase 3, open-label, randomised controlled trial. Lancet Oncol 2019; 20: 494-503. https://doi.org/10.1016/ s1470-2045(18)30896-9

33. Kalman NS, Weiss E, WalKer PR, Rosenman JG. Local radiotherapy intensification for locally advanced non-small-cell lung cancer - A call to arms. Clin Lung Cancer 2018; 19: 17-26. https://doi.org/10.1016/j. cllc.2017.05.024

34. Karam SD, Horne ZD, Hong RL, McRae D, Duhamel D, NaSR NM. Dose escalation with stereotactic body radiation therapy boost for locally advanced non small cell lung cancer. Radiat Oncol 2013; 8: 1-8. https://doi.org/10.1186/1748-717x-8-179

35. Feddock J, Arnold SM, Shelton BJ, Sinha P, Conrad G, Chen L et al. Stereotactic body radiation therapy can be used safely to boost residual disease in locally advanced non-small cell lung cancer : a prospective study. Radiat Oncol Biol 2013; 85: 1325-1331. https://doi.org/10.1016/j.ijrobp.2012.11.011

36. Kumar S, Feddock J, Li X, Shearer AJ, Hall L, Shelton BJ et al. Update of a prospective study of stereotactic body radiation yherapy for post-chemoradiation residual disease in stage II/III non-small cell lung cancer. Radiat Oncol Biol 2017; 99: 652-659. https://doi.org/10.1016/j.ijrobp.2017.07.036

37. Hepel JT, Leonard KL, Safran H, NG T, Taber A, Khurshid H et al. Stereotactic body radiation therapy boost after concurrent chemoradiation for locally advanced non-small cell lung cancer: a phase 1 dose escalation study. Int J Radiat Oncol Biol Phys 2016; 96: 1021-1027. https://doi.org/10.1016/j. ijrobp.2016.08.032

38. Higgins KA, Pillai RN, Chen Z, Tian S, Zhang C, Patel P et al. Concomitant chemotherapy and radiotherapy with sbrt boost for unresectable stage III non-small cell lung cancer: a phase I study. J Thorac Oncol 2017; 12: 1687-1695. https://doi.org/10.1016/j.jtho.2017.07.036

39. KIм YJ, KIm SS, Song SY, CHor EK. Feasibility of stereotactic radiotherapy for lung lesions and conventional radiotherapy for nodal areas in primary lung malignancies. Radiat Oncol 2018; 13: 127. https:// doi.org/10.1186/s13014-018-1071-5 
40. Nguyen NTA, Isfahanian N, Pond G, Hanna W, Cutz JC, Wright J et al. A novel neoadjuvant therapy for operable locally invasive non-small-cell lung cancer. Phase I study of neoadjuvant stereotactic body radiotherapy. LINNEARRE I (NCT02433574) Clin Lung Cancer 2017; 18: 436-440. https://doi. org/10.1016/j.cllc.2017.01.007

41. Singh AK, Hennon M, Ma SJ, Demmy TL, Picone A, Dexter EU et al. A pilot study of stereotactic body radiation therapy (SBRT) after surgery for stage III non-small cell lung cancer. BMC Cancer 2018; 29; 18: 1183. https://doi.org/10.1186/s12885-018-5039-5

42. Leaman Alcibar O, Candini D, López-Campos F, Albert Antequera M, Morillo Macías V, Conde AJ et al. Time for radioimmunotherapy: an overview to bring improvements in clinical practice. Clin Transl Oncol 2019; 21: 992-1004. https://doi.org/10.1007/s12094-018-02027-1

43. Golden EB, Chhabra A, Chachoua A, Adams S, Donach M, Fenton-Kerimian M et al. Local radiotherapy and granulocyte-macrophage colony-stimulating factor to generate abscopal responses in patients with metastatic solid tumours: a proof-of-principle trial. Lancet Oncol 2015; 16: 795-803. https://doi. org/10.1016/s1470-2045(15)00054-6

44. Shaverdian N, Lisberg AE, Bornazyan K, Veruttipong D, Goldman JW, Formenti SC et al. Previous radiotherapy and the clinical activity and toxicity of pembrolizumab in the treatment of non-small-cell lung cancer: a secondary analysis of the KEYNOTE-001 phase 1 trial. Lancet Oncol 2017; 18: 895-903. https://doi.org/10.1016/s1470-2045(17)30380-7

45. Tang C, Welsh JW, De Groot P, Massarelli E, Chang JY, Hess KR et al. Ipilimumab with stereotactic ablative radiation therapy: phase I results and immunologic correlates from peripheral $\mathrm{T}$ cells. Clin Cancer Res 2017; 23: 1388-1396. https://doi.org/10.1158/1078-0432.ccr-16-1432

46. U. S. National Library of Medicine. ClinicalTrials.gov identifier: NCT03833154. https://clinicaltrials. gov/ct2/show/NCT03833154

47. U. S. National Library of Medicine. ClinicalTrials.gov identifier: NCT03589547. https://clinicaltrials. gov/ct2/show/NCT03589547

48. U. S. National Library of Medicine. ClinicalTrials.gov identifier: NCT04003246. https://clinicaltrials. gov/ct2/show/NCT04003246 